\title{
Job Satisfaction among educators staff in public universities: Case study of UiTM Samarahan Sarawak
}

\author{
Jennifah Nordin, Nur Afisha Yusuf, Sarehan Sadikin, Zalina Mohd Desa* \\ Faculty of Administrative Science, Universiti Teknologi MARA, Kota Samarahan 94300, Sarawak, Malaysia
}

\section{A RT ICLE INFO}

\section{Article history:}

Received 4 November 2016

Received in revised form

4 January 2017

Accepted 7 January 2017

\section{Keywords:}

Job satisfaction

Educators

Work environment

Work commitment

Social relationship

\begin{abstract}
A B S T R A C T
This study main objective was to investigate the relationship between work commitment, work load, work environment, social relationship and remuneration with job satisfaction. While other objectives was to compare job satisfaction based on gender. A few hypotheses has been developed and tested. Out of 385 educators registered, 210 were selected as respondents. Simple random sampling technique was used to collect the data and data was collected within 2 weeks in the month of April 2014. The Pearson correlation test indicates that work commitment, work load, work environment, social relationship and remuneration had significant impact towards job satisfaction. While the result of t-test showed that there was no difference between male and female job satisfaction dealing with any aspect of applied sciences from fundamental sciences to applications in engineering systems and nature are solicited.
\end{abstract}

(C) 2017 The Authors. Published by IASE. This is an open access article under the CC BY-NC-ND license (http://creativecommons.org/licenses/by-nc-nd/4.0/)

\section{Introduction}

Nowadays, the role of educators is not only totally confined to teaching but they are also required to do a variety of tasks such as research, publication, innovation, admin work, social work, involvement with students activities and innovation. Thus, with high job demand, job satisfaction is very important to ensure a university will have a quality and motivated educators. There were numerous studies being conducted in relation to job satisfaction among educators in various country including Uganda, Turkey, USA, UK, Sweden, Mexico, Israel, Hong Kong, Germany Australia, Pakistan and Malaysia (Lacy and Sheehan, 1997; Ssesanga and Garret, 2005; Santhapparaj and Alam, 2005; Saifuddin and Allah, 2010; Toker, 2011; Colakoglu and Atabay, 2014; Abdul, 2013). The previous study conducted indicate to us that job satisfaction is very crucial among the educators, since its will influence high quality job commitment, high quality educators, high quality of teaching, high quality learning, high quality students and ability to create a successful education system. In addition capability of a university to managed educators job satisfaction will

\footnotetext{
* Corresponding Author.

Email Address: zalina@sarawak.uitm.edu.my (Z. M. Desa) https://doi.org/10.21833/ijaas.2017.03.012

2313-626X/@ 2017 The Authors. Published by IASE.

This is an open access article under the CC BY-NC-ND license

(http://creativecommons.org/licenses/by-nc-nd/4.0/]
}

help the university to retain educators' talents, enhance educators' loyalty, lower absenteeism and attracting more new prospective educators to join education industry (Noraani, 2013a). Therefore, the objective of this research was to identify the relationship between work commitment and job satisfaction, workloads and job satisfaction, work environment and job satisfaction, social relationship and job satisfaction, remuneration and job satisfaction. Other objective was to compare male and female job satisfaction.

Santhapparaj and Alam (2005) in their study highlighted that even there are frequent studies related to job satisfaction on educator staffs in UK and US. However, in Malaysia, limited of research has been conducted in this area while the academic working environment and job demand also changing rapidly worldwide. The educators face difficulty to manage tensions with the changing of workplace, especially in developing countries (Ssesanga and Garret, 2005). Furthermore, other researches highlighted that educators who are not happy with their workplace were more expose and experience depression, low mood, anxiety, hopeless, worthless, restless, loss of appetite and loss of concentration (Aziz et al., 2014). Their research findings which conducted in Malaysia revealed that only 5.1\% out of the total respondent's i.e. 317 educators experience high level of happiness. Thus, the researcher interested to pursue with this area of study. 


\section{Methodology}

Previous research and literature had study a lot of factors which contribute job satisfaction among the higher institution educators. Among the factors that lead to job satisfaction are pay, work, promotion, coworkers, support of research, support of teaching, fringe benefits, working conditions and supervision. However this study only discussed a few factors which contribute to educator's job satisfaction including work commitment, workloads, work environment, social relationship and remuneration. In addition, the paper also discussed the influence of gender to job satisfaction as discussed below:

\subsection{Work load and job satisfaction}

Study conducted in Southern Nigeria by Akpofure et al. (2006) indicated that even most educators were not satisfied with their job but they were satisfied with their workload. Moreover, a study conducted by Noraani (2013b) also presented similar findings where there is a moderately strong correlation between daily workload among educators with their job satisfaction. Thus, the following hypothesis is developed:

$\mathrm{H} 1$ : There is significant relationship between workload and job satisfaction.

\subsection{Work commitment and job satisfaction}

Commitment is interrelated to satisfaction. Marmaya (2008) studied reported that there were a few studies conducted to investigate the relationship between job satisfaction and job commitment. It is believed that satisfied workers will be committed to their job and remains in the organization, while dissatisfied workers will intend to quit. Another study conducted by Fletcher (2007) in Kuching Sarawak among the counseling educators found that there was significant relationship between job satisfaction and work commitment. Thus, based on previous literature the following hypothesis has been developed:

$\mathrm{H} 2$ : There is significant relationship between work commitment and job satisfaction.

\subsection{Working environment and job satisfaction}

Working environment consists of working hours, job safety and security, esteem needs and relationship with top management and co-workers (Raziq and Maulabakkhsh, 2015). Study conducted by the two abovementioned researchers reported that there was positive relationship between working environment and job satisfaction. Other study conducted in Dominos Jaipur City indicates that working environment has an impact on job satisfaction. Thus, the following hypothesis has been developed:
H3: There is significant relationship between working environment and job satisfaction.

\subsection{Social relationship and job satisfaction}

In life, social relationship is part of satisfaction which permits and provides an opportunity to employees to socialize such as having a lunch, taking a break and meeting customers. This will create a team cohesiveness and sense of belonging among the members of an organization and study conducted by Noraani (2013b) proved that there was positive significant relationship between interpersonal relationship and job satisfaction. While study conducted by Oshagbemi (2003) confirmed that having a good rapport with their colleagues will be able to increase educators' job satisfaction. Thus, based on previous literature the following hypothesis has been developed:

H4: There is significant relationship between social relationship and job satisfaction.

\subsection{Remuneration and job satisfaction}

Remuneration may include salary, bonus, commission, allowances, medical benefit, education facilities, transportation and insurance. A study conducted by Noraani (2013a) in four public universities in Kelantan which involved 320 respondents proved that salary has an impact to job satisfaction. These research findings are similar with study conducted by Santhapparaj and Alam (2005), which revealed that pay and fringe benefits were significantly influence job satisfaction. Thus, by referring to past research, the following hypothesis has been developed:

H5: There is significant relationship between remuneration and job satisfaction.

\subsection{Gender and job satisfaction}

When discussing about gender differences in job satisfaction perspective, previous literature two possibilities result where some proved that females were more satisfied than man and vice versa or no differences between male and female. Santhapparaj and Alam (2005) mentioned in their study that female educators' staffs were more satisfied than male educators. The opposite, Sabharwal and Corley (2009) found out there was significant differences between male and female educators as per their discipline of study (science, social science, engineering and health). Overall result show female educators were less satisfied compared to male educators. A study conducted in Turkey also has similar findings where males educators were more satisfied than female (Ayhan et al., 2012). Lacy and Sheehan (1997) has conduct a study on job satisfaction among academic staff at international perspective for eight countries including Australia, Germany, Hong Kong, Israel, Mexico, Sweden, UK and USA showed that male educators are more satisfied 
compared to female educators. While, a few study indicated that there was no significant differences between male and female in terms of job satisfaction (Oshagbemi, 2003; Ali and Akhter, 2009).

The dependent variable in the study is job satisfaction, while the independent variable consists of work load, work commitment, working environment, social relationship, working environment and gender as described in Fig. 1.

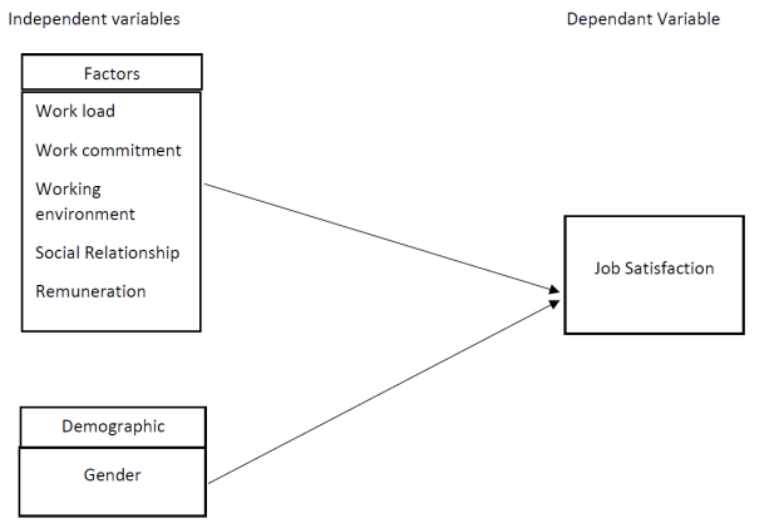

Fig. 1: Conceptual framework job satisfaction based on the literature

\subsection{Population and sampling size}

The study is considered as hypotheses testing and examines the relationship between the independent variables that are work load, work commitment, working environment, social relationship, remuneration and gender with the independent variable that is job satisfaction. The data was collected randomly from educators in UiTM Samarahan Sarawak which comprises of 385 educators both in Campus 1 and Campus 2. The numbers of educators was at as February 2014. By using Krejcie Morgan sampling technique, a total of 210 respondents were chosen as respondents. Data was collected during the first and second week of April 2014 from both campuses.

\subsection{Data measurement and data analysis}

There were 54 questionnaire items was developed from a various past researchers comprises of questions related to work load, work commitment, working environment, social relationship, remuneration and gender and job satisfaction as its dependent variable. Table 1 shows the source of reference to develop the questionnaires. A 5 point Likert scale is used to evaluate answer ranging from strongly disagree, disagree, neutral, agree and strongly agree.

The Pearson correlation is performed to identify the relationship between work loads, work commitment, working environment, social relationship, remuneration and job satisfaction. Furthermore, t-test is conducted to compare job satisfaction between male and female.

Table 1: Source of reference

\begin{tabular}{ccc}
\hline Variables & Type of Variables & Sources \\
\hline Workload & Independent & Akpofure et al. (2006); Noraani (2013a) \\
Work commitment & Independent & Marmaya (2008); Fletcher, (2007) \\
Working environment & Independent & Jain and Kaur (2014) \\
Social relationship & Independent & Santhapparaj and Alam (2005); Noraani (2013b) \\
Remuneration & Independent & Marmaya (2008); Santhapparaj and Alam (2005) \\
Gender & Independent & Lacy and Sheehan (1997); Oshagbemi (2003); Santhapparaj and Alam (2005); \\
Job satisfaction & Dependent & Sabharwal and Corley (2009); Ali and Akhter (2009); Ayhan et al., (2012) \\
\hline
\end{tabular}

\section{Results and discussion}

Out of 210 total respondents and total questionnaires distributed, only 154 questionnaires were returned and able to be analyzed. The demographic profile of respondents is shown in Table 2. While the relationships of work load, work commitment, working environment, social relationship, remuneration with job satisfaction are presented in Tables 3-7. While the influence of job satisfaction based on gender is shown in Table 8 .

The relationship between workload, work commitment, working environment, social relationship and remuneration and job satisfaction can be seen in Table 3 .

Based on the result in Table 3 reported that there is moderate positive relationship between workload and job satisfaction with $(r=522, p<0.05) \mathrm{p}=$ 0.000 . It indicated that workload has influence job satisfaction. Thus, $\mathrm{H} 1$ is accepted and $\mathrm{H} 0$ is rejected.
The subsequent objective is to identify the relationship between work commitment and job satisfaction. The analysis output in Table 4 reported that there is weak positive relationship between work commitment and job satisfaction with $(\mathrm{r}=331$, $\mathrm{p}<0.05$ ) $\mathrm{p}=0.000$. Thus, $\mathrm{H} 2$ is accepted and H0 is rejected.

The third objective is to identify the relationship between working environment and job satisfaction. This is to identify whether working environment such as the surrounding of campus and office has influence educators job satisfaction. Table 5 reported that there is also weak positive relationship between working environment and job satisfaction with ( $\mathrm{r}=$ $273, p<0.05$ ) $p=0.000$. Thus, H3 is accepted and H0 is rejected.

By referring to Table 6, it proven that there is a weak positive relationship between social relationship and job satisfaction with $(r=234, \mathrm{p}<$ 0.05), $\mathrm{p}=0.000$. Thus, $\mathrm{H} 4$ is accepted and $\mathrm{H} 0$ is rejected. 
Table 2: Respondents demographic profile

\begin{tabular}{|c|c|c|c|}
\hline Variables & Demographics & No of Respondents (Frequency) & Percentage (\%) \\
\hline \multirow{5}{*}{ Age } & $20-25$ & 5 & 3.2 \\
\hline & $26-30$ & 36 & 23.4 \\
\hline & $31-35$ & 53 & 34.4 \\
\hline & $35-40$ & 37 & 24.0 \\
\hline & 41 and above & 23 & 14.9 \\
\hline \multirow{2}{*}{ Gender } & Male & 45 & 29.2 \\
\hline & Female & 109 & 70.8 \\
\hline \multirow{7}{*}{ Length of Service } & Less than 3 years & 50 & 32.5 \\
\hline & $4-6$ years & 41 & 26.6 \\
\hline & 7-9 years & 22 & 14.3 \\
\hline & $10-12$ years & 19 & 12.3 \\
\hline & $13-15$ years & 14 & 9.1 \\
\hline & $16-19$ years & 2 & 1.3 \\
\hline & 20 years and above & 6 & 3.9 \\
\hline \multirow{3}{*}{ Level of Education } & Degree & 7 & 4.5 \\
\hline & Master & 141 & 91.6 \\
\hline & PHD & 6 & 3.9 \\
\hline \multirow{2}{*}{ Marital Status } & Single & 65 & 42.2 \\
\hline & Married & 89 & 57.8 \\
\hline
\end{tabular}

Table 3: Relationship between workload and job satisfaction

\begin{tabular}{cccc}
\hline & & Workload & Job Satisfaction \\
\cline { 2 - 3 } Workload & Pearson Correlation & 1 & 0.522 \\
& Sig. (2 tailed) & & 0.000 \\
& $\mathrm{~N}$ & 154 & 154 \\
Job Satisfaction & & 0.522 & 1 \\
& Pearson Correlation & 0.000 & 154 \\
\hline
\end{tabular}

Table 4: Relationship between work commitment and job satisfaction

\begin{tabular}{cccc}
\hline & & Work Commitment & Job Satisfaction \\
\cline { 2 - 3 } Work Commitment & Pearson Correlation & 1 & 0.331 \\
& Sig. (2 tailed) & & 0.000 \\
& $\mathrm{~N}$ & 154 & 154 \\
Job Satisfaction & Pearson Correlation & 0.331 & 1 \\
& Sig. (2 tailed) & 0.000 & 154 \\
\hline
\end{tabular}

Table 5: Relationship between working environment and job satisfaction

\begin{tabular}{|c|c|c|c|}
\hline \multirow{4}{*}{ Working Environment } & \multirow{3}{*}{$\begin{array}{l}\text { Pearson Correlation } \\
\text { Sig. ( } 2 \text { tailed) }\end{array}$} & \multirow{2}{*}{$\begin{array}{c}\text { Working Environment } \\
1\end{array}$} & \multirow{2}{*}{$\frac{\text { Job Satisfaction }}{0.273}$} \\
\hline & & & \\
\hline & & & .000 \\
\hline & $\mathrm{N}$ & 154 & 154 \\
\hline \multirow{3}{*}{ Job Satisfaction } & Pearson Correlation & 0.273 & 1 \\
\hline & Sig. (2 tailed) & 0.000 & \\
\hline & $\mathrm{N}$ & 154 & 154 \\
\hline
\end{tabular}

Table 6: Relationship between social relationship and job satisfaction

\begin{tabular}{cccc}
\multicolumn{4}{c}{ Table 6: Relationship between social relationship and job satisfaction } \\
\hline & & Social Relationship & Job Satisfaction \\
\cline { 3 - 3 } Social Relationship & Pearson Correlation & 1 & 0.234 \\
& Sig. (2 tailed) & & 0.000 \\
& $\mathrm{~N}$ & 154 & 154 \\
Job Satisfaction & Pearson Correlation & 0.234 & 1 \\
& Sig. (2 tailed) & 000 & 154 \\
\hline
\end{tabular}

The Pearson correlation is used to analyze the relationship between remuneration and job satisfaction. It intended to examine the influence of pay, bonus, insurance and other form of benefits influence to educator's job satisfaction. The result shown in Table 7 revealed that there is weak positive relationship between remuneration and job satisfaction with $(r=319, \mathrm{p}<0.05) \mathrm{p}=0.000$. Thus, $\mathrm{H} 5$ is accepted and $\mathrm{HO}$ is rejected.
The comparison of educators' gender with job satisfaction

Independent Sample t-test was used to examine whether there is differences on job satisfaction among the educators based on gender. Result in Table 8 show that there is no significant difference in employee job satisfaction either female or male when $\mathrm{t}(152)=-0.966, \mathrm{p}<0.05$. 
Table 7: Relationship between remuneration and job satisfaction

\begin{tabular}{|c|c|c|c|c|c|c|}
\hline & \multirow{2}{*}{\multicolumn{3}{|c|}{$\begin{array}{c}\text { Pearson Correlation } \\
\text { Sig. ( } 2 \text { tailed }) \\
\text { N }\end{array}$}} & \multicolumn{2}{|c|}{ Remuneration } & Job Satisfaction \\
\hline Remuneration & & & & \multicolumn{2}{|c|}{154} & $\begin{array}{c}0.319 \\
0.000 \\
154\end{array}$ \\
\hline Job Satisfaction & \multicolumn{3}{|c|}{$\begin{array}{c}\text { Pearson Correlation } \\
\text { Sig. ( } 2 \text { tailed) } \\
\mathrm{N} \\
\end{array}$} & \multicolumn{2}{|c|}{$\begin{array}{c}0.319 \\
0.000 \\
154 \\
\end{array}$} & $\begin{array}{c}1 \\
154 \\
\end{array}$ \\
\hline \multicolumn{7}{|c|}{ Table 8: Gender and job satisfaction } \\
\hline & & \multicolumn{2}{|c|}{$\begin{array}{c}\text { Levene Test for } \\
\text { Equality of Variances } \\
\end{array}$} & \multicolumn{3}{|c|}{ T test for Equality Means } \\
\hline & & $\mathrm{F}$ & Sig. & $\mathrm{t}$ & $\mathrm{df}$ & Sig. (2-tailed) \\
\hline \multirow{2}{*}{ Job Satisfaction } & $\begin{array}{l}\text { Equal Variance } \\
\text { assumed }\end{array}$ & 3.217 & .075 & -.966 & 152 & .336 \\
\hline & $\begin{array}{l}\text { Equal Variance } \\
\text { not assumed }\end{array}$ & & & -1.104 & 112.998 & .272 \\
\hline
\end{tabular}

\section{Conclusion}

Factors contributing to job satisfaction are work load, work commitment, working environment, social relationship and remuneration with job satisfaction. It means that the research findings are similar with previous literature review as discussed in section 2. However, in terms of comparing gender and job satisfaction, the research finding is similar with research conducted by Oshagbemi (2003), Ali and Akhter (2009) that there is no significance differences between male and female in relation to job satisfaction.

This study expected will able to create new knowledge to future researchers who are interested to conduct a similar study. However, the limitation of the study is the data could not be generalized for whole educators job satisfaction in public universities within Malaysia context generally and Sarawak specifically. The findings only represent job satisfaction among educators in UiTM Samarahan Sarawak. Besides that, one in terms of methodology only questionnaires is used to collect response from the respondents. The researchers recommend future researchers to widen the scope of study such as public universities in Borneo which include Sabah and Sarawak or in Malaysia that will include also a few public universities in West Malaysia and East Malaysia i.e. Sabah and Sarawak. Beside questionnaire, future researchers may also conduct interview by having focus group interview to have more accurate data.

\section{Acknowledgment}

We would like to express our sincere thanks to our colleagues in UiTM Samarahan Sarawak who were willingly to participate and response to our survey and especially to Nurdiyanah Shahari and Norkhalilah Duriat who have helped us in completing this study.

\section{References}

Abdul QC (2013). Job satisfaction of university teachers across the demographics (A case of Pakistani universities). Bulletin of Education and Research, 35(1): 1-15.

Akpofure RR, Ikhifa OG, Imide OI, and Okokoyo IE (2006). Job satisfaction among educatos in colleges of education in Southern Nigeria. Journal of Applied Sciences, 6(5): 10941098.

Ali T and Akhter I (2009). Job satisfaction of faculty members in private universities-In context of Bangladesh. International Business Research, 2(4): 167-175.

Ayhan A, Sengul U, and Yilmaz S (2012). The effect of gender on job satisfaction of teachers: A meta-analysis study. Procedia Social and Behavioural Sciences, 46: 356-362.

Aziz R, Mustaffa S, Samah NA, and Yusof R (2014). Personality and happiness among academicians in Malaysia. Procedia Social and Behavioral of Sciences, 116: 4209-4212.

Colakoglu N and Atabay E (2014). Job satisfaction of the academic staff of the vocational schools of the foundation and public university: Sample of Turkey. Quality Assurance in Education, 22(2): 185-206.

Fletcher F (2007). Hubungan tahap kecerdasan emosi dengan tahap kepuasan kerja dan tahap komitmen kerja di kalangan guru bimbingan dan kaunseling sekolah menengah di Bandaraya Kuching, Sarawak. M.Sc. Thesis, Universiti Teknologi Malaysia, Skudai, Johor Bahru, Malaysia.

Jain R and Kaur S (2014). Impact of work environment on job satisfaction. International Journal of Scientific and Research Publications, 4(1): 1-8.

Lacy FJ and Sheehan BA (1997). Job satisfaction among academic staff: An international perspective. Higher Education, 34(3): 305-322.

Marmaya NH (2008). The impact of organizational variables on job stress among teachers in Sabah. Institute of Research, Development and Commercialization, Universiti Teknologi MARA, Malaysia

Noraani M (2013a). The influence of financial reward on job satisfaction among academics staff at public universities in Kelantan, Malaysia. International Journal of Business and Social Science, 4(3): 244-248.

Noraani M (2013b). Measuring job satisfaction from the perspective of interpersonal relationship and faculty workload among academic staff at public universities in Kelantan, Malaysia. International Journal of Business and Social Science, 4(15): 120-124. 
Oshagbemi T (2003). Personal correlates of job satisfaction: Empirical evidence form UK universities. International Journal of Social Economics, 20(12): 1210-1232.

Raziq A and Maulabakhsh R (2015). Impact of working environment on job satisfaction. Procedia Economics and Finance, 23: 717-725.

Sabharwal M and Corley EA (2009). Faculty job satisfaction across gender and discipline. The Social Science Journal, 46(3): 539 556.

Saifuddin K and Allah N (2010). Impacts of demographic variables on job satisfaction of the academicians in universities of NWFP, Pakistan. Bulletin of Education and Research, 32(1): 53-68.
Santhapparaj AS and Alam SS (2005). Job satisfaction among academic staff in private universities in Malaysia. Journal of Social Sciences, 1(2): 72-76.

Ssesanga K and Garrett RM (2005). Job satisfaction of university academics: Perspective of Uganda. Higher Education, 50(1): 33-56.

Tella A, Ayeni CO and Popoola SO (2007). Work motivation, job satisfaction, and organisational commitment of library personnel in academic and research libraries in Oyo State, Nigeria. Library Philosophy and Practice, 16: 118-135.

Toker B (2011). Job satisfaction of academic staff: An empirical study on Turkey. Quality Assurance in Education, 19(2): 156169. 